\title{
Northern Eurasian large lakes history: sediment records obtained in the frame of Russian-German research project "PLOT"
}

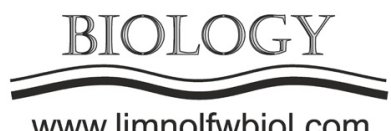

\author{
Fedorov G. ${ }^{1,2 *}$, Andreev A. ${ }^{3}$, Baumer M. ${ }^{4}$, Bolshiyanov D. ${ }^{2}$, Cherezova A. ${ }^{5}$, \\ Gromig R. ${ }^{4}$, Kostromina N. ${ }^{1}$, Kostrova S. ${ }^{3}$, Krastel S. ${ }^{6}$, Lebas E. ${ }^{6}$, Ludikova A. ${ }^{7}$, \\ Melles M. ${ }^{4}$, Meyer H. ${ }^{3}$, Pestryakova L. ${ }^{8}$, Savelieva L. ${ }^{1}$, Shumilovskikh L. ${ }^{9}$, \\ Subetto D. ${ }^{10}$, Wagner B. ${ }^{4}$, Wennrich V. ${ }^{4}$, Werner M. ${ }^{11}$ \\ ${ }^{1}$ St. Petersburg State University, Universitetskaya Nab. 7/9, St. Petersburg, 199034, Russia \\ ${ }^{2}$ Arctic and Antarctic Research Institute, Bering Str. 38, St. Petersburg, 199397, Russia \\ ${ }^{3}$ Department of Polar Terrestrial Environmental System, Alfred Wegener Institute Helmholtz Centre for Polar and Marine Research, \\ ${ }^{4}$ Telegrafenberg A43 Potsdam, 14473, Germany \\ ${ }^{4}$ Institute of Geology and Mineralogy, University of Cologne, Zulpicher Str. 49a, Cologne, 50674, Germany \\ ${ }^{5}$ A.P. Karpinsky Russian Geological Research Institute (FGBU-“VSEGEI"), 74, Sredny prospect, St. Petersburg, 199106, Russia \\ ${ }^{6}$ Institute of Geosciences, University of Kiel, Otto-Hahn-Platz 1, Kiel, D-24118, Germany \\ ${ }^{7}$ Institute of Limnology, Russian Academy of Sciences, Sevastyanova 9, St. Petersburg, 196105, Russia \\ ${ }^{8}$ Department for Geography and Biology, North-eastern Federal University of Yakutsk, Belinskogo 58, Yakutsk, 67700, Russia \\ ${ }^{9}$ Department of Palynology and Climate Dynamics, Georg-August University of Gottingen, Wilhelm-Weber-Str. 2a, Gottingen, 37073, \\ Germany \\ ${ }^{10}$ Herzen State Pedagogical University of Russia, emb. Moika 48, St. Petersburg, 191186, Russia \\ ${ }^{11}$ Department of Climate Science, Alfred Wegener Institute Helmholtz Centre for Polar and Marine Research, Bussestrasse 24, \\ Bremerhaven, 27570, Germany
}

\begin{abstract}
Russian-German project PLOT (Paleolimnological Transect) aims at investigating the regional responses of the quaternary climate and environment on external forcing and feedback mechanisms along a more than $6000 \mathrm{~km}$ long longitudinal transect crossing Northern Eurasia. The well-dated record from Lake El'gygytgyn used as reference site for comparison the local climatic and environmental histories. Seismic surveys and sediment coring up to $54 \mathrm{~m}$ below lake floor performed in the frame of the project on Ladoga Lake (North-West of Russia; 2013), Lake Bolshoye Shchuchye (Polar Ural; 2016), Lake Levinson-Lessing and Lake Taymyr (Taymyr Peninsula; 2016-2017), Lake Emanda (Verkhoyansk Range; 2017). Fieldwork at Polar Ural and Taymyr Peninsula was conducted in collaboration with the Russian-Norwegian CHASE (Climate History along the Arctic Seaboard of Eurasia) project. Here, we present the major results of the project obtained so far.
\end{abstract}

Keywords: Russian-German project "PLOT", Northern Eurasian large lakes, Late Quaternary environments

\section{Introduction}

Despite much progress made over the last decades, the nature and reasons of climate variability on Earth still are insufficiently understood. This is particularly true for the Eurasian North, which currently is experiencing a much more pronounced warming then the rest of the globe. The strongly amplified warming of the northern territories is unprecedented in historical times. It most likely is due to anthropogenic greenhouse gas emissions along with complex feedback mechanisms involving the atmospheric and oceanic circulation, sea-ice cover, vegetation, and permafrost behaviour.
In order to differentiate between natural and anthropogenic climate change, and to decipher the environmental changes resulting from climate variations, a thorough knowledge of the climatic and environmental history prior to human impact is needed. This information can only be achieved from the investigation of natural geoscientific archives that reflect regional changes through time with sufficient time-resolution and sensitivity.

For the vast landmasses of the Eurasian Arctic many of the natural archives so far investigated are of limited value to understand the climatic and environmental history. Marine sediment cores from the Arctic Ocean integrate over very large areas, reflect the 
environmental change on the continent only indirectly, and often have a rather poor time-resolution and age control. Ice cores, on the other hand, usually have a much better time-resolution and age control, however, they only exist from northwestern Eurasia, where they are limited in age to the last few millennia. Permafrost sediments have a wide areal distribution and partly long time-range, but they often are discontinuous and the paleoclimatic information is restricted due to their variable genesis in a highly dynamic environment. Lake sediments better integrate over areas, in many cases are formed continuously, and often can properly be dated. The problem encountered with lake sediments is that most of the records existing are limited in age to the Holocene and Late Weichselian.

Recently, however, much progress has been made to explore and retrieve longer sediment records from lakes in the Eurasian Arctic. The most prominent example is Lake El'gygytgyn that was the subject of an international ICDP drilling project that resulted in the recovery of the longest continuous palaeoclimatic and palaeoenvironmental record for the terrestrial Arctic covering the last 3.6 million years (Melles et al., 2012; Brigham-Grette et al., 2013).

Russian-German project PLOT (Paleolimnological Transect) aims at investigating the regional responses of the quaternary climate and environment on external forcing and feedback mechanisms along a more than $6000 \mathrm{~km}$ long longitudinal transect crossing Northern Eurasia using the well-dated record from Lake El'gygytgyn as reference site for comparison the local climatic and environmental histories.

\section{Materials and methods}

In order to reconstruct the climatic and environmental history during Late Quaternary times seismic surveys and sediment coring performed on five lakes, which together with Lake El'gygytgyn form a more than $6000 \mathrm{~km}$ long longitudinal transect across northern Eurasia.

During the pilot stage of the project in 2013 about $1500 \mathrm{~km}$ of seismic profiles were performed and two long (18 $\mathrm{m}$ and $22 \mathrm{~m}$ ) sediment cores were retrieved in northern part of Lake Ladoga that is largest European lake located in North-West of Russia. In summer 2016 $54 \mathrm{~m}$-long sediment core was obtained in the central part of $130 \mathrm{~m}$ deep Lake Bolshoye Shchuchye located in Polar Ural. During 2016 and 2017 seismic surveys and sediment coring performed in Taymyr Peninsula on lakes Levinson-Lessing (47 m-long sediment core) and Taymyr (14 m and $16 \mathrm{~m}$-long sediment cores). In summer 2017 sediment echo sounding and coring (6 m-long sediment core) were performed on Lake Emanda (Verkhoyansk Range).

A multi-channel, high-resolution seismic reflection survey using a Micro-GI airgun and Innomar sediment echo sounding system were used for obtaining large-scale information on the depositional and post-depositional histories, and for selecting the most appropriate locations for coring. Sediment coring performed by using an improved UWITEC percussion piston corer.

For the reconstruction of the sedimentary processes a range of bulk analyses carried out on the sediment cores, including whole-core MSCL logging (physical properties, $1 \mathrm{~cm}$ spacing), half-core XRF scanning (chemical composition, 0.2 to $5 \mathrm{~mm}$ spacing), thin section microscopy (microstructures, irregularly) as well as water contents, grain-size distributions, organic and inorganic geochemistry (regular, every 4 to $16 \mathrm{~cm}$ ). The basic chronologies established by means of ${ }^{14} \mathrm{C}$ AMS and optically stimulated luminescence (OSL).

The paleoclimatological reconstructions particularly rely on palynological and diatom analyses.

\section{Results}

Some of the results recently published in special issue of journal Boreas (Melles et al., 2019) and more publications are coming with new special issue of Journal of Quaternary Science that is in progress.

The multiproxy studies of sediment core from largest European Lake Ladoga allow estimating a formation age of the Luga moraine close to Lake Ladoga's southern shore of 14.5-15.9 cal. ka BP (Gromig et al., 2019) that is significantly older than previously assumed. Lateglacial and Holocene climate, vegetation and paleohydrology history reconstructed based on palynological (Savelieva et al., 2019), diatom, and diatom-based oxygen isotope data (Kostrova et al., 2019).

The palynological data from the low part of the same core allow a first reconstruction of the Early Weichselian environmental history for northwestern Russia and reflect a climate more favorable than in the Holocene during MIS 5d (Andreev et al., 2019).

The analysis of the $54 \mathrm{~m}$-long sediment core from Lake Bolshoye Shchuchye revealed detailed Late Weichselian and Holocene environmental history of Polar Ural.

A seismic survey of Lake Levinson-Lessing and sediment core investigation allows to reconstruct the periods of ice advances, marine waters inundations, lacustrine and purely terrestrial conditions in central Taymyr Peninsula (Lebas et al., 2019).

Lateglacial and Holocene environmental history in the centre of Taymyr Peninsula reconstructed based on Lake Taymyr sediments investigations.

The multiproxy studies of sediment core from Lake Emanda in the Yana Highlands allow reconstructing the regional Late Quaternary climate and environmental history.

\section{Acknowledgments}

The PLOT project is conducted in the frame of a bilateral Russian-German agreement in the field of polar and marine research and is funded by the German and Russian Research Ministries. The work of G. Fedorov, and N. Kostromina was additionally supported by RFBR grant (18-05-60291). Fieldwork at Polar Ural and 
Taymyr Peninsula was conducted in collaboration with the Russian-Norwegian CHASE (Climate History along the Arctic Seaboard of Eurasia) project. The work of A. Ludikova contributes to the State Research Program of IL RAS № 0154-2019-0001.

\section{References}

Andreev A.A., Shumilovskikh L.S., Savelieva L.A. et al. 2019. Environmental conditions in northwestern Russia during MIS 5 inferred from the pollen stratigraphy in a sediment core from Lake Ladoga. Boreas 48: 377-386. DOI:10.1111/bor.12382

Brigham-Grette J., Melles M., Minyuk P. et al. 2013. Pliocene warmth, polar amplification, and stepped Pleistocene cooling recorded in NE Arctic Russia. Science 340: 14211427. DOI: $10.1126 /$ science. 1233137

Gromig R., Wagner B., Wennrich V. et al. 2019. Deglaciation history of Lake Ladoga (north-western Russia) based on varved sediments. Boreas 48: 330-348. DOI:10.1111/ bor.12379.
Kostrova S.S., Meyer H., Baile H.L. et al. 2019. Holocene hydrological variability of Lake Ladoga, northwest Russia as inferred from diatom oxygen isotopes. Boreas 48: 361-376. DOI:10.1111/bor.12385

Lebas E., Krastel S., Wagner B. et al. 2019. Seismic stratigraphic record of Lake Levinson-Lessing, Taymyr Peninsula: evidence for ice-sheet dynamics and lake-level fluctuations since the Early Weichselian. Boreas 48: 470-487. DOI:10.1111/bor.12381.

Melles M., Brigham-Grette J., Minyuk P.S. et al. 2012. 2.8 million years of Arctic climate change from Lake El'gygytgyn, NE Russia. Science 337: 315-320. DOI: 10.1126/ science.1222135

Melles M., Svendsen J.I., Fedorov G. \& Wagner B. 2019. Northern Eurasian Lakes - Late Quaternary glaciation and climate history: an introduction. Boreas 48: 269-272. DOI: 10.1111/bor.12395.

Savelieva L.A., Andreev A.A., Gromig G. et al. 2019. Vegetation and climate changes in northwestern Russia during the Lateglacial and Holocene inferred from the Lake Ladoga pollen record. Boreas 48: 349-360. DOI: 10.1111/ bor.12376. 